\title{
Bees Diversity on Flowers of Eremanthus spp. (Asteraceae)
}

\author{
Ana Paula de Souza Medeiros Santos ${ }^{1}$ (D), Sebastião Lourenço Assis Júnior ${ }^{1} \mathbb{( D}$, \\ Anete Pedro Lourenço ${ }^{1}$ (D), Evandro Luiz Mendonça Machado ${ }^{1}$ \\ ${ }^{1}$ Universidade Federal dos Vales do Jequitinhonha e Mucuri (UFVJM), Diamantina, MG, Brasil
}

\begin{abstract}
Bees are considered important pollinators due to their fidelity to plants, enabling the maintenance of gene flow between plant species. The objective of this study was to recognize the visit of bees in two Candeia species, Eremanthus erythropappus and Eremanthus incanus (Asteraceae), as well as to analyze the pollen content carried by bees in a regeneration area. Nine samplings were taken in each plant species using entomological nets. The pollen grains were obtained in 338 bees from their legs and bodies. The species Trigona spinipes, Apis mellifera, and Bombus pauloensis were most frequent. Candeias are essential in the study area because they have high adaptive potential, but besides them, other plants are also important for attracting bees searching for pollen and/or nectar.
\end{abstract}

Keywords: pollen analysis, pollinators, degradation. 


\section{INTRODUCTION AND OBJECTIVES}

Increasing anthropogenic activities through civil construction, mining, deforestation, and pollution is the main cause of fragmentation of natural habitats, leading to biodiversity loss (Hagen et al., 2012). When these practices are inadequate, they promote soil degradation and loss of vegetation cover, resulting in environmental imbalance (Gebremedhin et al., 2018).

Degraded areas lose their capacity of resilience and they require the man's actions to return to their former characteristics or to become as close as possible to the reference ecosystem. A recovery plan is essential in these areas to restore the environment to its basic functions (Andrade \& Romeiro, 2011).

In degraded areas where usually there are losses in biodiversity and in the relationships between living organisms, pollinators play an important role in reestablishing these relationships (Oliveira \& Engel, 2011). On the other hand, the reduction of plant cover can affect the community of pollinators, making scarce the availability of food and reducing the transfer of pollen between plants (Eckert et al., 2010).

The analysis of the pollen attached to the body of the bees has become an important tool to obtain data about foraging behavior (Silva, Aleixo et al., 2014). By this technique, it is possible to identify the most visited plants in a certain area, pointing out the main food resources used by the bees (Frias et al., 2016; Novais et al., 2009; Silva et al., 2010).

Candeias (Eremanthus spp.) are among the most important botanical species in Minas Gerais. Eremanthus erythropappus (DC.) McLeish and Eremanthus incanus (Less.) Less belong to the Asteraceae family and can be used for the recovery of degraded areas, as they are pioneers in field areas and adapted to nutrient-poor, rocky and sandy soils (Silva, Oliveira et al., 2014).

The wood of candeia can be used in the manufacture of fences by small farmers, and its oil is commercialized in the cosmetic and pharmaceutical industry (Lima et al., 2013). These characteristics are essential because they guarantee the recovery of degraded areas and allow economic return for the small rural producer (Oliveira, Andrade et al., 2010).

Besides its great economic importance, candeia presents a high percentage of viable pollen, although with little availability of nectar for floral visitors, who usually forage all day long with a foraging peak during the hottest hours (Barbosa et al., 2016; Oliveira, Dias et al., 2012; Vieira et al., 2012).

Biribiri State Park, in Diamantina, MG, has an area which has undergone a degradation process where gravel was removed for the construction of a highway bordering the park. Currently, this area undergoes a recovery process, with the planting of candeia, among other species with some of them belonging to the Fabaceae family (Branquinho et al., 2013, Silva, Pereira et al., 2014).

The objective of this work was to verify the main species of bees visiting Eremanthus erythropappus and Eremanthus incanus found in a gravel area in the plant recovery process and the alternative sources of food for these bees.

\section{MATERIALS AND METHODS}

The study was carried out in Biribiri State Park, located in the Southern Espinhaço Range, in High Jequitinhonha Valley in Diamantina, MG, between $18^{\circ} 14^{\prime} 53^{\prime \prime} \mathrm{S}$ and $43^{\circ} 39^{\prime} 57^{\prime \prime} \mathrm{W}$ and at an altitude approximately $1,300 \mathrm{~m}$ above sea level. The climate is typically tropical, $\mathrm{Cwb}$ in the Köppen classification. The average annual precipitation varies from $1,250 \mathrm{~mm}$ to $1,550 \mathrm{~mm}$ and the average annual temperature is between $18{ }^{\circ} \mathrm{C}$ and $19^{\circ} \mathrm{C}$. The relative air humidity is almost always high, with annual averages of 75.6\% (Neves et al., 2005).

The park has a vegetation characteristic of the Cerrado biome. The predominant plant formations are the savannas and grasslands, and forest formations such as Cerradão and Semidecidual Seasonal Forest are also found, mainly along the streams and rivers slopes (Gonzaga et al., 2014).

The study area called gravel area comprises 8.4 hectares and it is in the process of recovery. The process of degradation started with the removal of gravel for the construction of the highway BR-367, bordering the park. In 2002, the process of recovery began by planting species adapted to the region. E. erythropappus and E. incanus stand out among them, as they have shown great adaptive potential.

The samplings were done in two stages, beginning with the appearance of the first flowering plants and ending with the end of each flowering period. 
The first stage was carried out in 41 flowering plants of E. erythropappus between July $23^{\text {rd }}$ and August $24^{\text {th }}$, 2012. The samplings were done once a week, totaling five days of samplings (samplings 1 to 5), with effort of 42 hours. The second stage occurred after the flowering period of E. erythropappus, which coincided with the appearance of the first flowers of $E$. incanus. Its flowering period occurred between August $30^{\text {th }}$ and September $19^{\text {th }}, 2012$, with weekly samplings totaling four days of samplings ( 6 to 9), with an effort of 35 hours, in 18 plants. The collection period was from 8 a.m. to 5 p.m. for both species. The method used to capture the bees was the "sweep" type, using entomological nets. The collections were performed simultaneously by two collectors, in different plants, for five minutes each, following the methodology used by Viana et al. (2002).

The captured individuals were sacrificed and taken to the Bee Genetics Laboratory of Universidade Federal dos Vales do Jequitinhonha e Mucuri (UFVJM). The identification was based on dichotomous keys (Silveira et al., 2002), done by specialists or by comparison with species already identified. The specimens were deposited in the "Coleção de Abelhas" of this University.

When present, the pollen was removed from the legs and body of the bees. The pollen samples were submitted to the acetolysis process. Three slides were prepared with glycerinated gelatin for each sample after the process (Barth \& Duarte, 2008). The pollen grains were photomicrographed and identified in types, following a pollen catalog of cerrado plants (Bastos et al., 2008). The quantitative analysis was performed counting 500 pollen grains per slide. The pollen types were classified according to the frequency in the slide, being dominant those with representation above $45 \%$, accessories between $16 \%$ and $45 \%$, and occasional with up to $15 \%$.

The characterization of the community of bees was performed through the abundance, richness, constancy, dominance, and frequency of faunal indexes according to D’Avila \& Marchini (2008).

The climatic data were obtained through the Climatological Normals maintained by INMET. Spearman's correlation (Rs) was performed using the Bioestat 5.0 software to correlate bee abundance with mean temperatures on each day of sampling.

\section{RESULTS AND DISCUSSION}

Thirteen species of bees belonging to three families were collected: Apidae, Andrenidae, and Halictidae. Collected bees from Apidae belonged to two subfamilies (Apinae and Xylocopinae) and from Andrenidae and Halictidae to only one subfamily each (Panurginae and Halictinae, respectively) (Table 1).

A total of 338 individuals were collected in both species of candeia. The Apidae family was the most representative with $99.1 \%$ of the individuals (Table 2).

Table 1. Bees visiting flowers of Eremanthus erythropappus and Eremanthus incanus in a gravel pit area located at Biribiri State Park, Diamantina, MG, 2012.

\begin{tabular}{|c|c|c|}
\hline Family & Subfamily & Species \\
\hline \multirow{11}{*}{ Apidae } & \multirow{9}{*}{ Apinae } & Apis mellifera Linnaeus, 1758 \\
\hline & & Bombus (Fervidobombus) pauloensis Friese, 1913 \\
\hline & & Bombus (Fervidobombus) morio (Swederus, 1787) \\
\hline & & Geotrigona mombuca (Smith, 1863) \\
\hline & & Melipona (Melikerria) quinquefasciata Lepeletier, 1836 \\
\hline & & Melipona (Melipona) quadrifasciata Lepeletier, 1836 \\
\hline & & Trigona fulviventris Guérin Méneville, 1845 \\
\hline & & Trigona spinipes (Fabricius, 1793) \\
\hline & & Centris sp. \\
\hline & \multirow{2}{*}{ Xylocopinae } & Xylocopa (Neoxylocopa) sp. \\
\hline & & Xylocopa sp. \\
\hline Adrenidae & Panurginae & Morphospecies \\
\hline Halictidae & Halictinae & Morphospecies \\
\hline
\end{tabular}


Table 2. Bees visitors (\%) in flowers of Eremanthus erythropappus and Eremanthus incanus in the area of gravel located in Biribiri State Park, Diamantina, MG, 2012.

\begin{tabular}{llccccc}
\multicolumn{1}{c}{ Family } & \multicolumn{1}{c}{ Subfamily } & $\begin{array}{c}\text { Number of } \\
\text { genera }\end{array}$ & $\begin{array}{c}\text { Number } \\
\text { of species }\end{array}$ & $\begin{array}{c}\text { Number of } \\
\text { individuals }\end{array}$ & $\begin{array}{c}\text { Eremanthus } \\
\text { erythropappus (\%) }\end{array}$ & $\begin{array}{c}\text { Eremanthus } \\
\text { incanus (\%) }\end{array}$ \\
Apidae & Apinae & 6 & 9 & 331 & 68.28 & 31.72 \\
Adrenidae & Pylocopinae & 1 & 2 & 4 & 0.00 & 100.00 \\
Halictidae & Halictinae & 1 & 1 & 2 & 0.00 & 100.00 \\
\hline Total & & 9 & 13 & 338 & 0.00 & 100.00 \\
\hline
\end{tabular}

There are five bee families in Brazil: Andrenidae, Apidae, Halictidae, Colletidae, and Megachilidae (Silveira et al., 2002). This study verified the presence of bees belonging only to the first three. The distribution of bees in Brazil is related to the type of vegetation, with some endemic species. For example, in tropical rainforests in the south of the country, higher species richness of Halictidae family is observed (MiletPinheiro \& Schlindwein, 2008). In areas of cerrado, the family Apidae is the most representative, followed by Megachilidae. Andena et al. (2005), studying a Cerrado area in a country town of São Paulo, observed that the number of species can vary between 103 to 189 and the number of individuals collected can reach 3,010. Because the present work was carried out on only two species of plants and during its flowering period, the number of bee species observed was low.

A. mellifera, T. spinipes and B. pauloensis were constant and dominant species; the others were accidental or accessory. In the first stage, that is, in the flowering period of E. erythropappus, five collections were performed and a total of 226 individuals were observed, distributed in one family, five genera and six species. Only individuals belonging to Apidae family were collected. B. pauloensis was the dominant species with $79.73 \%$ of the individuals collected, followed by A. mellifera with $14.98 \%$. In the second stage, i.e., the flowering period of E. incanus, 112 individuals were collected, distributed in three families, seven genera and 13 species. The Apidae family was again the most abundant with $97.32 \%$, followed by Andrenidae with $1.78 \%$ and Halictidae with $0.89 \%$ of the individuals. T. spinipes was the most abundant species with $44.64 \%$, followed by B. pauloensis with $35.71 \%$ of the individuals. T. fulviventris, Centris sp., M. quadrifasciata, Xylocopa sp. and one species of the subfamily Halictinae were occasional with only one individual collected (Table 3).
In the present study, B.pauloensis and T. spinipes were considered constant and dominant in E. erythropappus and $E$. incanus, respectively. These species belong to the Apidae family and are characterized by presenting colonies with a communication system and generalist foraging behavior (Castillo et al., 2015; Gonzalez et al., 2004). A similar pattern was found by Vieira et al. (2012), when studying the floral biology of E. incanus. In general, bees prefer to visit Asteraceae flowers in surveys conducted in areas of cerrado or rupestrian fields. This is due to the large number of species of this family in this biome that supply pollen and nectar (Andena et al., 2005). The flowering period of E. erythropappus and $E$. incanus occurred in the dry and cold season, as observed by Vieira et al. (2012); thus, these two species are food resources for bees during a period of two months. One of the striking characteristics of Cerrado is the fact that the flowering of many plant species is synchronized with the seasons. In this biome, it is possible to observe the flowering of some species during the dry and cold season and others during the beginning of the rainy season (Lenza \& Klink, 2006). E. erythropappus and E. incanus flowering occur in the cold and dry season, where there is usually a scarcity of resources, making this species an important source of food for bees. Candeia presents dense inflorescences with an average of 29 open flowers, increasing the supply of pollen and nectar to its visitors (Vieira et al., 2012). A large supply of flowers in a given environment contributes to the maintenance of bee populations due to the greater supply of food resources (Dick et al., 2003). This is important in an area where degradation processes are still visible and available food resources are scarce. The five collections performed in E. erythropappus were characterized by the great abundance of bees, especially B. pauloensis, which were collected during the warmer hours of the day (close to 1 p.m.). In this period of collection, days 
Table 3. Species richness and faunal indices of bees collected in flowers of Eremanthus erythropappus and Eremanthus incanus in a gravel pit area located at Biribiri State Park, Diamantina, MG, 2012.

\begin{tabular}{|c|c|c|c|c|c|c|}
\hline Taxon & Eremanthus erythropappus & Eremanthus incanus & $\mathbf{A b}$ & $\mathrm{Co}^{1}$ & Fr & $\mathrm{Do}^{2}$ \\
\hline Apis mellifera & 34 & 3 & 37 & $\mathrm{C}$ & 0.109 & $\mathrm{D}$ \\
\hline Bombus pauloensis & 181 & 40 & 221 & $\mathrm{C}$ & 0.653 & $\mathrm{D}$ \\
\hline Bombus morio & 2 & 2 & 4 & $\mathrm{AC}$ & 0.011 & ND \\
\hline Geotriona mombuca & 1 & 3 & 4 & $\mathrm{AD}$ & 0.011 & ND \\
\hline Melipona quinquefasciata & 3 & 4 & 7 & $\mathrm{AC}$ & 0.020 & ND \\
\hline Melipona quadrifasciata & 0 & 1 & 1 & $\mathrm{AD}$ & 0.002 & ND \\
\hline Trigona fulviventris & 0 & 1 & 1 & $\mathrm{AD}$ & 0.002 & $\mathrm{ND}$ \\
\hline Trigona spinipes & 5 & 50 & 55 & $\mathrm{C}$ & 0.162 & $\mathrm{D}$ \\
\hline Centris sp. & 0 & 1 & 1 & $\mathrm{AD}$ & 0.002 & ND \\
\hline Xylocopa (Neoxylocopa) sp. & 0 & 3 & 3 & $\mathrm{AD}$ & 0.008 & ND \\
\hline Xylocopa sp. & 0 & 1 & 1 & $\mathrm{AD}$ & 0.002 & ND \\
\hline Panurginae & 0 & 2 & 2 & $\mathrm{AD}$ & 0.006 & ND \\
\hline Halictinae & 0 & 1 & 1 & $\mathrm{AD}$ & 0.002 & ND \\
\hline Total & 226 & 112 & 338 & & & \\
\hline
\end{tabular}

$\mathrm{Ab}$ : abundance; Co: constancy; Fr: frequency; Do: dominance; ${ }^{1} \mathrm{C}$ : constant; $\mathrm{AC}$ : accessory; AD: accidental; ${ }^{2} \mathrm{D}$ : dominant; ND: non-dominant.

were marked by low temperatures, strong winds, and sporadic rain, mainly in the morning. However, from the sixth to the ninth days temperatures were higher and there was a reduction of the wind intensity and rain amount. This stage was marked by increased richness with the presence of seven other species: T. fulviventris,
Panurginae, Centris sp.1, Halictinae, M. quadrifasciata, Xylocopa (Neoxylocopa) sp. and Xylocopa sp. There was also a prevalence of $T$. spinipes as one of the most abundant species. There was no significant correlation between bees' richness and mean temperatures on collection days (Rs $=0.4767 ; p=0.1494$ ) (Figure 1$)$.

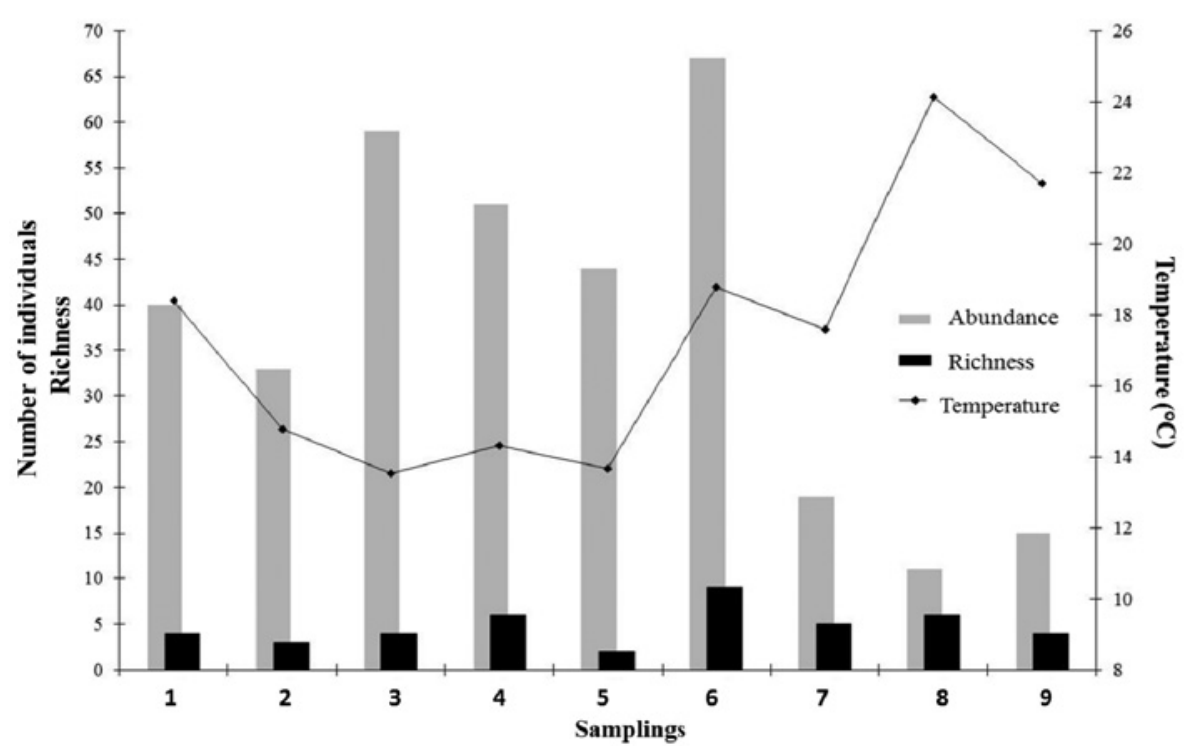

Figure 1. Relationship between abundance and richness of bees with average temperature in nine days of samplings. From the first to the fifth day, sampling was performed in flowers of Eremanthus erythropappus, and from the sixth to the ninth, in flowers of Eremanthus incanus. Diamantina, MG, 2012. 
The number of visiting species increased during the flowering period of $E$. incanus when compared to E. erythropappus. Seven new species were collected in the flowers of $E$. incanus, although with a lower abundance. The two candeia species flourished one after the other and synchronously. Synchronized production of flowers of different species for a short period of time could attract the attention of generalist pollinators, while asynchronous flowering species would attract specialized pollinators (Janzen, 1974). Despite the increase in species richness in the second stage, only one individual was collected in some species. These bees remained for a short time in the flowers, and can be considered as occasional or pillage, having low contribution in the process of pollination of the species. Therefore, bees considered occasional in this work did not present pollen adhered to the body, which limited the pollen analysis of these bees.

The highest species richness of bees collected in E. incanus flowers can also be attributed to the increase in temperature during the collection days. Although there was no correlation between the average temperature in the days of collection and the bees' richness, the first stage was highlighted by low temperatures with a great abundance of individuals, mainly of B. pauloensis, while in the second stage, the collections were performed on hot days, without strong winds or rain. The temperature may be a limiting factor in the flight activities of some bee species, especially for small ones (Gouw \& Gimenes, 2013; Oliveira et al., 2012). Bombus is a robust bee and, for the study area, this species seems to play an important role since they perform their activities even on cold days and with strong winds where no other species is observed foraging (Araújo et al., 2006). In addition, B. pauloensis presents a wide diversity of habitats used for nesting, including forests, savannas, pastures, and even disturbed environments (Gonzalez et al., 2004). The study area offers adequate nesting sites for this species, often observed entering holes in the soil covered by dry grass.

Due to the great similarity between E. erythropappus and $E$. incanus pollen and the difficulty in distinguishing between the two pollen types, both were considered as Eremanthus spp. (Figure 2A-B). Pollen was removed from those bees with a large amount of it in their body. The pollen found in the bees' bodies was distributed in five plant families and six pollen types (Figure 2).
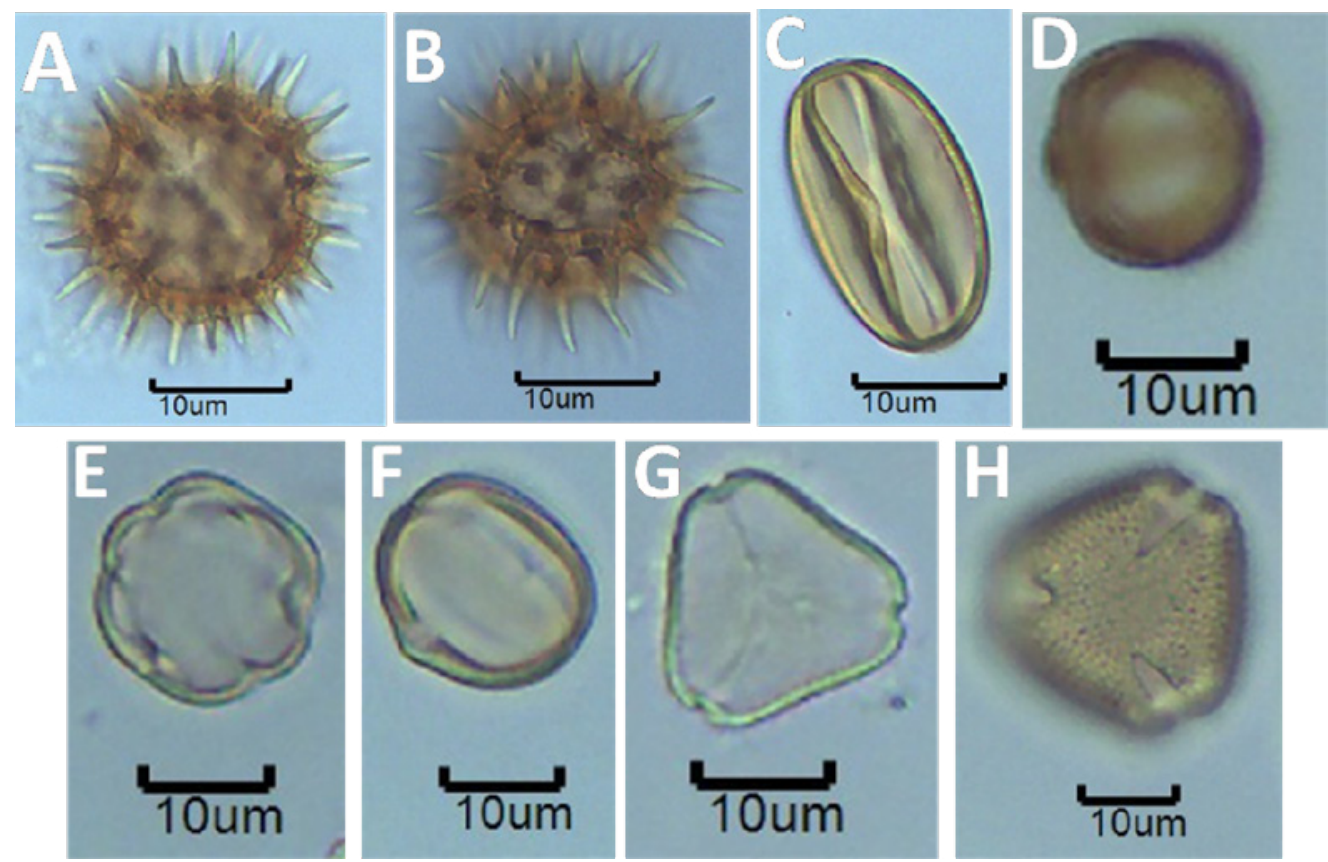

Figure 2. Pollen types adhered to bees' bodies. The bees were collected in flowers of Eremanthus erythropappus and Eremanthus incanus in a gravel pit area located at Biribiri State Park, Diamantina, MG, 2012. A-B: Eremanthus sp.; C: Fabaceae Chamaecrista sp.1; D: Lamiaceae type 1; E-F: Melastomataceae Tibouchina sp.; G: Myrtaceae type 1; $\mathrm{H}$ : Myrtaceae type 2 . 
In the samples collected in the first stage, the pollen from Eremanthus sp. was dominant only in T. spinipes with $73.15 \%$. In B. pauloensis, the largest variety of types was observed, and Tibouchina sp. (Figure 2E-F) and Myrtaceae type 1 (25.96\%) (Figure 2G) were the most representative (Table 4$)$.

In the second stage, the pollen from Eremanthus sp., Tibouchina sp. and Myrtaceae type 1 were dominant in the samples of A. mellifera, B. pauloensis, and B. morio, with $84.68 \%, 95.41 \%$ and $93.34 \%$, respectively. All samples had Eremanthus sp. pollen, although it was considered occasional in some bee species (Table 5).

Other plant species showed flowering in the same period of Eremanthus spp. During the collection period, plants from other botanical families such as Amarantaceae, Melastomataceae and Myrtaceae were blooming and also provided food resources for the bees. The analysis of the pollen carried by the bees in the two stages revealed the presence of six pollen types. This result shows that bees do not have a broad spectrum of pollen resources used in the area, perhaps due to the reduced number of plants in the area. Eremanthus pollen was dominant only in the eusocial species $T$. spinipes and A. mellifera. The behavior of these bees as floral visitors is because they are opportunists rather than specialists, exploiting those available resources to the maximum with high density (Kleinert \& Giannini, 2012). A. mellifera, for example, shows preference for Asteraceae plants and especially those that show mass flowering as candeia species (Maruyama et al., 2018). The preference for Asteraceae flowers in Cerrado biome has already been observed and may be related to the great diversity of species of this family in different areas (Mota et al., 2018). The largest variety of pollen types was observed in the B. pauloensis bees. These bees usually have large niche amplitude (CortopassiLaurino et al., 2003), which may vary according to the characteristics of each area, such as the diversity and availability of plants in the area (Franco et al., 2009).

Among the pollen types carried by B. pauloensis, those of Tibouchina sp. (Melastomataceae) found in the first and second stages deserves attention. In the studies carried out in rupestrian fields, relationships between bees of the genus Bombus and flowers of poricidal anthers are reported (Cortopassi-Laurino et al., 2003). These bees are large and capable of performing pollination by vibration, which is restricted to certain bee groups (Silva, Ballesteros et al., 2010). In the study area, the species of

Table 4. Average frequency (\%) of pollen types found in the body of bees visiting Eremanthus erythropappus in a gravel area located at Biribiri State Park, Diamantina, MG, 2012.

\begin{tabular}{llcc}
\multicolumn{1}{c}{ Family } & \multicolumn{1}{c}{ Pollen types } & Bombus pauloensis & Trigona spinipes \\
\hline \multirow{2}{*}{ Asteraceae } & Eremanthus sp. & 3.77 & $73.15^{*}$ \\
& Vernonanthura sp. & 2.14 & 26.85 \\
\multirow{2}{*}{ Melastomataceae } & Tibouchina sp. & $55.99^{*}$ & - \\
& Melastomataceae type & 5.25 & - \\
\multirow{2}{*}{ Myrtaceae } & Myrtaceae type 1 & 25.96 & - \\
& Myrtaceae type 2 & 6.89 & - \\
\hline
\end{tabular}

${ }^{*}$ Dominant pollen $(>45 \%)$.

Table 5. Average frequency (\%) of pollen types found in the body of bees visiting Eremanthus incanus in a gravel area located at Biribiri State Park, Diamantina, MG, 2012.

\begin{tabular}{|c|c|c|c|c|}
\hline Family & Pollen types & Bombus morio & Bombus pauloensis & Apis mellifera \\
\hline \multirow{2}{*}{ Asteraceae } & Eremanthus sp. & 6.03 & 11.08 & $95.41^{\star}$ \\
\hline & Vernonanthura sp. & 0.63 & 0.36 & 3.46 \\
\hline Fabaceae & Chamaecrista sp. & - & 3.81 & - \\
\hline Lamiaceae & Lamiaceae type & - & 0.05 & - \\
\hline Melastomataceae & Tibouchina sp. & - & $84.68^{*}$ & 1.13 \\
\hline Myrtaceae & Myrtaceae type 1 & $93.34^{*}$ & 0.02 & - \\
\hline
\end{tabular}

${ }^{\star}$ Dominant pollen $(>45 \%)$. 
Melastomataceae, mainly Tibouchina sp., appear to be important sources of pollen. The presence, in greater quantity, of Bombus spp. in Eremanthus flowers probably occurs more by the demand for nectar, since the pollen frequency of other families such as Melastomataceae and Myrtaceae was higher. However, the use of Eremanthus spp. pollen is more frequent by A. mellifera and T. spinipes.

\section{CONCLUSIONS}

- The eusocial bees Bombus pauloensis, Trigona spinipes, and Apis mellifera were the ones with the highest occurrence in the two species of Eremanthus.

- The pollen of Eremanthus spp. showed higher frequency in Trigona spinipes and Apis mellifera.

- Bombus pauloensis was responsible for the greater variety of pollen, demonstrating that, in addition to candeia species, other families such as Melastomataceae and Myrtaceae are important sources of food resources for these bees in the study area.

\section{SUBMISSION STATUS}

Received: 24 June, 2016

Accepted: 25 Oct., 2018

\section{CORRESPONDENCE TO}

\section{Sebastião Lourenço Assis Júnior}

Universidade Federal dos Vales do Jequitinhonha e Mucuri (UFVJM), Engenharia Florestal, Rodovia MGT 367, km 588, 5.000, CEP 39100-000,Diamantina, MG, Brasil e-mail: assisjr_ento@yahoo.com.br

\section{FINANCIAL SUPPORT}

The authors thank Coordenacão de Aperfeiçoamento de Pessoal de Nível Superior (Capes) for the financial support.

\section{REFERENCES}

Andena SR, Bego LR, Mechi MR. A comunidade de abelhas (Hymenoptera, Apoidea) de uma área de cerrado (Corumbataí, SP) e suas visitas às flores. Revista Brasileira de Zoociências 2005; 7(1): 55-91.
Andrade DC, Romeiro AR. Degradação ambiental e teoria econômica: algumas reflexões sobre uma "economia dos ecossistemas". Economia 2011; 12(1): 3-26.

Araújo VA, Antonini Y, Araújo APA. Diversity of bees and their floral resources at altitudinal areas in the Southern Espinhaço Range, Minas Gerais, Brazil. Neotropical Entomology 2006; 35(1): 30-40. 10.1590/ S1519-566X2006000100005

Barbosa FM, Campos LAO, Paixão JF, Alves RMO. Foraging pattern and harvesting of resources of subterranean stingless bee Geotrigona subterranea (Friese, 1901) (Hymenoptera: Apidae: Meliponini). Papéis Avulsos de Zoologia 2016; 56(12): 151-157. 10.11606/00311049.2016.56.12

Barth OM, Duarte SG. Morfologia polínica de espécies arbóreas de Solanaceae do estado de Santa Catarina, Brasil. Hoehnea 2008; 35(3): 379-386. 10.1590/S223689062008000300005

Bastos EMAF, Thiago PSS, Santana RM, Travassos A. Banco de imagens de grãos de pólen: mais de 130 espécies de plantas apícolas. Ribeirão Preto: Universidade de São Paulo; 2008.

Branquinho FGG, Barbosa GP, Pereira IM, Carvalho TF. Regeneração natural em cascalheira em recuperação por meio do uso de topsoil. Enciclopédia Biosfera 2013; 9(17): 2297-2305.

Castillo RC, Sanabria-Urbán S, Serrano-Meneses MA. Trade-offs in the evolution of bumblebee colony and body size: a comparative analysis. Ecology and Evolution 2015; 5(18): 3914-3926. 10.1002/ece3.1659

Cortopassi-Laurino M, Knoll FR, Imperatriz-Fonseca VL. Nicho trófico e abundância de Bombus morio e Bombus atratus em diferentes biomas brasileiros. In: Melo GAR, Alves-dos-Santos I, editores. Apoidea neotropica: homenagem aos 90 anos de Jesus Santiago Moure. Criciúma: Editora Unesc; 2003. p. 285-295.

D’Avila M, Marchini LC. Análise faunística de himenópteros visitantes florais em fragmento de cerradão em Itirapina, SP. Ciência Florestal 2008; 18(2): 271-279. $10.5902 / 19805098465$

Dick CW, Etchelecu G, Austerlitz F. Pollen dispersal of tropical trees (Dinizia excelsa: Fabaceae) by native insects and African honeybees in pristine and fragmented Amazonian rainforest. Molecular Ecology 2003; 12(3): 753-764. 10.1046/j.1365-294X.2003.01760.x

Eckert CG, Kalisz S, Geber MA, Sargent R, Elle E, Cheptou $\mathrm{PO}$ et al. Plant mating systems in a changing world. Trends in Ecology and Evolution 2010; 25(1): 35-43. 10.1016/j. tree.2009.06.013

Franco EL, Aguiar CML, Ferreira VS, Oliveira-Rebouças PL. Plant use and niche overlap between the introduced honey bee (Apis mellifera) and the native bumblebee (Bombus atratus) (Hymenoptera: Apidae) in an area of 
tropical mountain vegetation in Northeastern Brazil. Sociobiology 2009; 53(1): 141-150.

Frias BED, Barbosa CD, Lourenço AP. Pollen nutrition in honey bees (Apis mellifera): impact on adult health. Apidologie 2016; 47(1): 15-25. 10.1007/s13592-015-0373-y

Gebremedhin H, Gebresamual G, Abadi N, Hailemariam M, Teka K, Mesfin S. Conversion of communal grazing land into arable land and its impacts on soil properties and vegetation cover. Arid Land Research Management 2018; 32(2): 236-252. 10.1080/15324982.2017.1406412

Gonzaga APD, Martins MB, Gonzaga APD, Pereira IM. Influência da declividade do terreno no crescimento de três espécies em uma área em processo de recuperação no Parque Estadual do Biribiri em Diamantina, MG. MG. Biota 2014; 2: 4-20.

Gonzalez VH, Mejia A, Rasmussen C. Ecology and nesting behavior of Bombus atratus Franklin in Andean highlands (Hymenoptera: Apidae). Journal of Hymenoptera Research 2004; 13(2): 28-36.

Gouw MS, Gimenes, M. Differences of the daily flight activity rhythm in two neotropical stingless bees (Hymenoptera, Apidae). Sociobiology 2013; 60(2): 183189. 10.13102/sociobiology.v60i2.183-189

Hagen M, Kissling WD, Rasmussen C, Aguiar MAM, Brown LE, Carstensen DW et al. Biodiversity, species interactions and ecological networks in a fragmented world. Advances in Ecological Research 2012; 46: 89-120. 10.1016/B978-0-12-396992-7.00002-2

Janzen DH. Why do bamboos wait so long to flower? Annual Review of Ecology and Systematics 1974; 7: 347391. 10.1146/annurev.es.07.110176.002023

Kleinert AMP, Giannini TC. Generalist bee species on Brazilian bee-plant interaction networks. Psyche 2012; 291519. 10.1155/2012/291519

Lenza E, Klink CA. Comportamento fenológico de espécies lenhosas em um cerrado sentido restrito de Brasília, DF. Revista Brasileira de Botânica 2006; 29(4): 627-638. 10.1590/S0100-84042006000400013

Lima FWJ, Dantas Barros NA, Soares, BM, Santos DA, Resende MA, Carvalho MAR et al. The composition and anti-microbial activity of essential oil from Eremanthus erythropappus (DC) Macleish (Candeia). International Journal of Medicinal and Aromatic Plants 2013; 3(1): 1-10.

Maruyama PK, Nunes CEP, Vizentin-Bugoni J, Gustafsson S, Morellato LPC. Are native bees and Apis mellifera the same for a generalist flower? Assessing the relative contribution of pollinators for a rupestrian grassland daisy, Aspilia jolyana (Asteraceae). Acta Botanica Brasilica 2018; 32(3): 386-391. 10.1590/0102-33062018abb0143

Milet-Pinheiro P, Schlindwein C. Comunidade de abelhas (Hymenoptera, Apoidea) e plantas em uma área do Agreste pernambucano, Brasil. Revista Brasileira de Entomologia 2008; 52(4): 625-636. 10.1590/S0085-56262008000400014
Mota GS, Luz GR, Mota NM, Coutinho ES, Dores MMV, Fernandes GW et al. Changes in species composition, vegetation structure, and life forms along an altitudinal gradient of rupestrian grasslands in south-eastern Brazil. Flora 2018; 238: 32-42. 10.1016/j.flora.2017.03.010

Neves SC, Abreu, PAA, Fraga LMS. Fisiografia. In: Silva AC, Pedreira LCVSF, Abreu PAA, editores. Serra do Espinhaço Meridional: paisagens e ambientes. Belo Horizonte: O Lutador; 2005. p. 47-58.

Nogueira-Ferreira FH, Augusto SC. Amplitude de nicho e similaridade no uso de recursos florais por abelhas eussociais em uma área de cerrado. Bioscience Journal 2007; 23(1): 45-51.

Novais JS, Lima LCL, Santos FAR. Botanical affinity of pollen harvested by Apis mellifera $\mathrm{L}$. in a semi-arid area from Bahia, Brazil. Grana 2009; 48(3): 224-234. 10.1080/00173130903037725

Oliveira AD, Andrade IS, Scolforo JRS, Mello JM, Rezende JLP. Economic analysis of sustainable management of candeia. Cerne 2010; 16(3): 335-345. 10.1590/S0104-77602010000300009

Oliveira FL, Dias VHP, Costa EM, Filgueira MA, Sobrinho JE. Influência das variações climáticas na atividade de voo das abelhas jandairas Melipona subnitida Ducke (Meliponinae). Revista Ciência Agronômica 2012; 43(3): 598-603.

Oliveira RE, Engel VL. A restauração ecológica em destaque: um retrato dos últimos vinte e oito anos de publicações na área. Oecologia Australis 2011; 15(2): 219-231. 10.4257/oeco.2011.1502.08

Santos GM, Carvalho CAL, Aguiar CML, Macêdo LSSR, Mello MAR. Overlap in trophic and temporal niches in the flower-visiting bee guild (Hymenoptera, Apoidea) of a tropical dry forest. Apidologie 2013; 44(1): 64-74. 10.1007/s13592-012-0155-8

Silva CI, Aleixo KP, Nunes-Silva B, Freitas BM, Imperatriz-Fonseca VL. Guia ilustrado de abelhas polinizadoras no Brasil. São Paulo: Universidade de São Paulo; 2014 [cited 2019 May 29]. Available from: https://bit.ly/2la8iGs

Silva CI, Ballesteros PLO, Palmero MA, Bauermann SG, Evaldt ACP, Oliveira PE. Catálogo polínico: palinologia aplicada em estudos de conservação de abelhas do gênero Xylocopa no Triângulo Mineiro. Uberlândia: Edufu; 2010.

Silva CSJ, Oliveira AD, Coelho LM Jr, Scolforo JRS, Souza AN. Viabilidade econômica e rotação florestal de plantios de candeia (Eremanthus erythropappus), em condições de risco. Cerne 2014; 20(1): 113-122. 10.1590/ S0104-77602014000100015

Silva NF, Pereira IM, Oliveira MLR, Santana RC, Carlos L. Initial growth of Eremanthus erythropappus in recovery of a gravel pit in Diamantina, Brazil. Australian Journal of Basic and Applied Sciences 2014; 8: 298-306. 
Silveira FA, Melo GAR, Almeida EAB. Abelhas brasileiras: sistemática e identificação. Belo Horizonte: Composição e Arte; 2002.

Viana BF, Kleinert AMP, Neves EL. Comunidade de Euglossini (Hymenoptera, Apidae) das dunas litorâneas do Abaeté, Salvador, Bahia, Brasil. Revista Brasileira de Entomologia 2002; 46(4): 539-545. 10.1590/S008556262002000400008

Vieira AF, Fajardo CG, Carvalho D. Biologia floral da candeia (Eremanthus erythropappus, Asteraceae). Pesquisa Florestal Brasileira 2012; 32(72): 477-481. 10.4336/2012. pfb.32.72.477 